\title{
ANNOUNCEMENT
}

\section{INTERNATIONAL GEOLOGICAL CONGRESS XVIII SESSION, LONDON, 1948}

The XVIII Session of the International Geological Congress, originally planned for 1940 and postponed on the outbreak of war, is to be held in Great Britain in 1948, on the invitation of the Geological Society of London.

A Third Circular containing preliminary arrangements for the Session has been issued. Sessional Meetings will take place in London from 25th August to 1st September, 1948, and the following subjects have been provisionally listed for discussion :-

1. Problems of Geochemistry.

2. Metasomatic Processes in Metamorphism.

3. Rhythm in Sedimentation.

4. The Geological Results of Applied Geophysics.

5. The Geology of Iron-Ore Deposits.

6. The Geology of Petroleum.

7. The Geology, Paragenesis and Reserves of the Ores of Lead and Zinc.

8. The Geology of Sea and Ocean Floors.

9. The Pliocene-Pleistocene Boundary.

10. Faunal and Floral Facies and Zonal Correlation.

11. The Correlation of Continental Vertebrate-bearing Rocks.

12. Earth Movements and Organic Evolution.

The Circular gives details of geological excursions covering most of the British Isles, which are planned to take place between 7th August and 18th September, 1948, as part of the Congress programme. They include 16 long excursions (7-16 days) before the meetings in London, and 16 of similar length after the meetings. There will also be daily excursions, centred on London, between 22nd August and 3rd September.

The General Organizing Committee is anxious that the plans for the Session, which will be the first major international assembly of geologists for eleven years, shall be as widely known as possible. About 1,500 geologists, including some 800 from countries overseas, would have attended in 1940 if the arrangements for that year had not been disrupted by war ; it is hoped that the attendance in 1948 will be of the same order, and that it will include representatives of universities, geological surveys, geological and mining societies, and other interested institutions from most countries of the world.

Sir Thomas Holland, K.C.S.I., F.R.S., is President of the General 
Organizing Committee and President-Designate of the Congress. The General Secretaries are Mr. A. J. Butler and Dr. L. Hawkes, and the Treasurer is Mr. F. N. Ashcroft. All communications should be addressed to the General Secretaries, XVIII Session International Geological Congress, Geological Survey and Museum, Exhibition Road, London, S.W. 7.1

24th April, 1947.

\section{CORRESPONDENCE}

SiR,- - I am engaged on a nomenclatorial revision of Da niel Sharpe's Monograph of the Chalk Cephalopods, published by the Paleontographical Society. In this connection I am trying to trace the present location of all the specimens which he figured.

I have located those in the British, Geological Survey, and Norwich Museums, but there are still nearly fifty specimens unaccounted for, most important of which are those in the Wiest Collection which were not presented by that collector to Sharpe.

If any of your readers has any clue to the whereabouts of the Wiest collection or any knowledge of the presence of specimens figured by Sharpe in collections other than the three I have mentioned, I should be very glad to be informed.

\section{TOWER House, NORTH FERRIBY, EAST YoRKSHIRE. \\ C. W. WRIGHT.}

4th May, 1947. 